\title{
Improvement of Production Process on the Basis of Application of Principles of Lean Production at the Machine-Building Enterprise
}

\author{
Svetlana Chinazirova \\ Economy and Management Department \\ Adyghe State University \\ Maykop, Russia \\ E-mail: Svetlana.9992015@yandex.ru \\ Angela Pshizova \\ Economy and Management Department \\ Adyghe State University \\ Maykop, Russia \\ E-mail: angelika_agu@mail.ru
}

\author{
Alexander Mokrushin \\ Economy and Management Department \\ Adyghe State University \\ Maykop, Russia \\ E-mail: Mokrushin_alex@inbox.ru \\ Kaplan Tamov \\ Economy and Management Department \\ Adyghe State University \\ Maykop, Russia \\ E-mail: tamov-ka@mail.ru
}

\begin{abstract}
The article discusses the basic methods and principles of lean production as a modern management, based on the desire to eliminate all types of losses. The purpose, principles, tools and systems of lean production are defined. The article assesses the effectiveness of the introduction of lean production elements on the example of PJSC "ZAREM". To improve the production process of the machine-building enterprise for lean production, the method "wheel lean production" is used, which includes a strategic, intellectual, production and resource triangle.
\end{abstract}

Keywords-lean production; Kaizen; $5 S$ system; SMED system; TRM system; JIT system; Kanban system; production cycle; strategic triangle; intellectual triangle; production triangle; resource triangle

\section{INTRODUCTION}

The relevance of the use of lean production (BP) to improve the activities of the organization is due to the rapid pace of development in the modern economy. An increasing number of organizations set themselves the task of reducing costs in accordance with the products and services provided by international quality standards. The Lean management concept and its associated methods and tools allow us to solve this problem by restructuring the production system in accordance with the experience of world-class leaders.

Implementation of lean production in practice is often a disordered process, due to the disunity of information about principles, methods and tools. In this regard, it becomes necessary to study the approaches of using this concept. A typical application of lean manufacturing is the manufacturing process.
Foreign authors and scientists such as Taiichi Ono, Masaaki Imai, Shigeo Shingo, James Wumek, Daniel David Mayer and Jeffrey Liker have made significant contributions to the development of BP ("Table I"). 
TABLE I. AUTHORS AND THEIR MAIN CONTRIBUTION TO BP

\begin{tabular}{|c|c|}
\hline $\begin{array}{c}\text { Authors, main works, year of publication of the } \\
\text { original }\end{array}$ & Main contribution \\
\hline $\begin{array}{l}\text { Taiichi Ono } \\
\text { Toyota production system. Moving away from mass } \\
\text { production [1] (1978) }\end{array}$ & $\begin{array}{l}\text { The principle of "just in time", Kanban. } \\
\text { Autonomization, (automation using intelligence) and "error protection" (poka-yoke). } \\
\text { The Ford system (narrow nomenclature, mass production, pushing) and the Toyota } \\
\text { production system (wide nomenclature, flow into one product, pulling) are compared. } \\
\text { Visual control, Andon. } \\
\text { Alignment of production (Heijunka), } \\
\text { The approach of the "Five whys". } \\
\text { Identification and elimination of losses, types of losses. } \\
\text { SOP (standardized operating procedures } \\
\text { procedures.) }\end{array}$ \\
\hline $\begin{array}{l}\text { Shigeo Shingo } \\
\text { Study of Toyota production system from the point of } \\
\text { view of production organization [2] (1981) } \\
\text { Fast readjustment: } \\
\text { Revolutionary technology } \\
\text { production optimization } \\
\text { (1985) [3] }\end{array}$ & $\begin{array}{l}\text { The main components of the process are highlighted: } \\
\text { processing, control, transportation, storage SMED (quick changeover). } \\
\text { Improving control (embedding quality, protecting against errors, stopping the process to } \\
\text { find the cause of the error). }\end{array}$ \\
\hline $\begin{array}{l}\text { The Sach Nakayama } \\
\text { Introduction to TPM: Universal } \\
\text { maintenance of equipment (1988) }\end{array}$ & $\begin{array}{l}\text { TPM: Universal equipment maintenance (a system that reduces breakdowns to almost zero } \\
\text { and increases productivity by as much as } 150 \text { percent). }\end{array}$ \\
\hline $\begin{array}{l}\text { Hiroyuki Hirano } \\
\text { 5S for workers: how to improve your workplace (1990) }\end{array}$ & The system of rational organization of workplaces $5 \mathrm{~S}$. \\
\hline $\begin{array}{l}\text { Masaaki Imai Kaizen: the key to the success of } \\
\text { Japanese companies (1986) [4] } \\
\text { Gemba Kaizen: the Way to reduce costs and improve } \\
\text { quality (1997) }\end{array}$ & $\begin{array}{l}\text { Kaizen (continuous improvement and maintenance with the participation of managers and } \\
\text { workers, is opposed to innovation). } \\
\text { Generalization of Japanese methods (Taiichi Ono, Kaoru Ishikawa, etc.). } \\
\text { Gemba (solving problems directly at production sites and workplaces). }\end{array}$ \\
\hline $\begin{array}{l}\text { Womac James P., Daniel Jones } \\
\text { The machine that changed the world (1990) [5] } \\
\text { Lean production: } \\
\text { How to get rid of losses and achieve prosperity of your } \\
\text { company (1996) [6] }\end{array}$ & $\begin{array}{l}\text { Introduction of the concept of "Lean production". } \\
\text { Approach to implementing Lean manufacturing. } \\
\text { Value stream mapping. } \\
\text { The eighth type of loss. }\end{array}$ \\
\hline $\begin{array}{l}\text { Mike Rother, John Shook } \\
\text { Learn to see business processes. The practice of } \\
\text { mapping flows } \\
\text { value creation (1998) [7] } \\
\text { John Shook, Chet Marchwinski } \\
\text { The illustrated Glossary of lean manufacturing (2003) } \\
\text { [8] }\end{array}$ & $\begin{array}{l}\text { Mapping the value stream (for a detailed description) } \\
\text { Detailed description of a large number of other BP tools }\end{array}$ \\
\hline $\begin{array}{l}\text { Thomas Jackson } \\
\text { Hoshin Kanri. How to make strategy work (2006) [9] }\end{array}$ & $\begin{array}{l}\text { Hoshin Kanri (policy deployment), A3-report, etc. } \\
\text { This method was used in many Japanese enterprises, including Toyota. }\end{array}$ \\
\hline $\begin{array}{l}\text { Jeffrey Liker } \\
\text { Toyota Dao: } 14 \text { management principles of the world's } \\
\text { leading company (2004) [10] } \\
\text { David Mayer and Jeffrey Liker } \\
\text { The practice of Tao Toyota. } \\
\text { Toyota management principles implementation guide } \\
\text { (2006) [11] }\end{array}$ & $\begin{array}{l}14 \text { principles of Toyota Hansei production system (recognition of its shortcomings, } \\
\text { introspection) } \\
\text { The decision process (A3-report, the process of "nemawashi") } \\
\text { 4P system (Philosophy-Philosophy, Process-process, People and partners-employees and } \\
\text { partners, Problem solving-problem Solving) }\end{array}$ \\
\hline
\end{tabular}

Proceeding from the considered works, it can be noted that Lean production was formed in a separate concept of the 80s of the XX century, while the basis was the Production system of Toyota. However, the term "Lean production" was introduced later in the United States, this time can also be noted by the systematization of experience and methodologies in this area.

Literature in Russian is represented quite widely, at the moment there are more than 50 books on the subject of BP. The most popular book with a circulation of more than 78,000 copies is the Tao of Toyota: 14 principles of management of the world's leading company [12].

Since 2014, Russia has developed a number of standards for Lean production.
According to the results of the study, it is possible to provide information about organizations where lean production methods and tools are used, as well as some other objects related to lean production. These organizations affect many areas of industry and services.

Below are some organizations grouped by type of activity, considered the beginning of the implementation of the concept of BP. ("Table II") 
TABLE II. Russian Organizations That Have IMPLEMENTEd the ConCEPT of LEAN Production [13]

\begin{tabular}{|l|l|l|}
\hline \multicolumn{1}{|c|}{ Type of activity } & \multicolumn{1}{|c|}{ Organization name } & Start of implementation \\
\hline Motor industry & GAZ group & 2003 \\
\cline { 2 - 3 } & KAMAZ vehicle & 2006 \\
\hline Banking sector & Sberbank of Russia & 2008 \\
\hline Logistics services, transport & RZD & 2010 \\
\hline Aircraft building & Irkutsk aviation plant & 2008 \\
\cline { 2 - 3 } & $\begin{array}{l}\text { Company Sukhoi (Komsomolsk-on-Amur aviation plant named after Yuri } \\
\text { Gagarin, Novosibirsk aviation plant. V. P. Chkalova) }\end{array}$ & 2008 \\
\hline Metallurgy & RUSAL (Bratsk aluminum plant, Novokuznetsk aluminum plant) & 2006 \\
\cline { 2 - 3 } & $\begin{array}{l}\text { Alcoa (Samara plant, } \\
\text { Belaya Kalitva plant) }\end{array}$ & 2005 \\
\cline { 2 - 3 } & VSMPO-AVISMA & 2005 \\
\cline { 2 - 3 } & Severstal & 2010 \\
\hline $\begin{array}{l}\text { Atomic } \\
\text { industry }\end{array}$ & Rosatom & 2009 \\
\hline $\begin{array}{l}\text { Chemical } \\
\text { industry }\end{array}$ & SIBUR-holding & 2011 \\
\hline
\end{tabular}

"Table II" shows that the first industries in Russia to apply the principles of lean production were the automotive industry and metallurgy, now the concept has spread to a wide range of industries. However, the main trend is to apply the principles of lean manufacturing in industry. The exception is the company Sberbank.

The "Table II" shows mainly large holding companies that share their experience in open sources, but this is not an exhaustive list of companies that apply the concept of BP in their activities.

In Russia, the pioneer in the field of BP is considered Gorky Automobile Plant (GAZ). In 2002, the plant was visited by the first consultants from Japan, which was the beginning of the optimization of the production system [14].

The lean production system is based on the following methods and principles: value stream mapping; pull-flow production; continuous improvement (Kaizen); 5S system; SMED Single Minute Exchange of Dies system; TRM (Productive Maintenance) system; JIT (Just in time) system; Kanban system; visualization; and-shaped cells.

The main idea of the concept of continuous improvement (Kaizen) is the lack of equilibrium, static, everything is constantly rethinking, reassessment. Steady progress is ensured by continuous minor changes.

The "5S" system involves the formation of a transparent and rational organization of the environment, defining a specific place for each thing, which contributes to more effective management of production space and productivity. The "5S" system includes the following interrelated stages: sorting, maintaining order, keeping clean, standardization, improvement.

SMED (Single Minute Exchange of Dies) is a system of theoretical and practical methods that significantly reduce the downtime of the machine during its changeover, which allows you to increase productivity and reduce the volume of production waste. This technology contributes to more efficient and fast execution of customer orders.
A Just-in-time ("just-in-time") system is understood as a cycle during which a product or service passes from the raw material stage to the finished product stage. Delivery of materials and equipment in the required volume occurs only when it is required by a certain stage of the production process, which contributes to the dynamism and continuity of the working process, reducing the cost of storage and transportation.

In modern conditions, machine-building enterprises use creative methods and technologies of production management in order to minimize production costs associated with increased costs for raw materials and materials, as well as to reduce the cost of production and increase the profit of the enterprise.

Improvement of the production process through the introduction of lean production measures is carried out according to the following methodology by eliminating:

- unnecessary processing steps;

- overproduction;

- excess stock;

- unnecessary movements;

- unnecessary transportation;

- elimination of defects;

- eliminate expectations.

All activities are processed by an automated calculation system that analyzes their effectiveness in terms of these indicators and their groups.

The availability of the necessary information makes it possible to calculate the efficiency of lean production measures.

The obtained information on the results of the individual segments of the enterprise allows for an economic assessment of losses. In centers loss you need to create for registering information peculiar points of information 
be expected after the introduction of the principles and methods of lean production:

- reduce the production cycle of products;

- reduction of time to perform technological operations;

- reduced marriage rate;

- optimization of the number of personnel;

- increase of production culture [15].

To assess the efficiency of the machine-building enterprise for lean production, the method "wheel lean production" is used, which includes a strategic, intellectual, production and resource triangle. Each of these triangles shows the challenges and opportunities for further development of lean production in their respective areas.

To assess the factors of lean production of PJSC "ZAREM" the approach presented in "Table III" is used.

In accordance with the goal of the machine-building enterprise, the improvement of the production process should

TABLE III. EVALUATION INDICATORS OF EACH OF THE TRIANGLES

\begin{tabular}{|c|c|c|c|}
\hline № & $\begin{array}{c}\text { The name of the } \\
\text { triangle }\end{array}$ & The purpose of the triangle & Performance evaluation \\
\hline \multirow[t]{3}{*}{1} & \multirow[t]{3}{*}{ Strategic triangle } & \multirow{3}{*}{$\begin{array}{l}\text { The ability of the enterprise to form a development strategy, } \\
\text { philosophy of lean production and report it to the entire staff, as } \\
\text { well as the identification of key indicators for the subsequent } \\
\text { calculation of the performance of the enterprise. }\end{array}$} & Application of strategic management \\
\hline & & & Lean manufacturing philosophy \\
\hline & & & $\begin{array}{l}\text { Availability of key performance } \\
\text { indicators }\end{array}$ \\
\hline \multirow[t]{3}{*}{2} & \multirow[t]{3}{*}{ Intellectual triangle } & \multirow{3}{*}{$\begin{array}{l}\text { The need to involve senior management in the process, team } \\
\text { cohesion, the use of Kaizen technologies, conducting training } \\
\text { courses on the use of lean production tools in the management of } \\
\text { the enterprise. }\end{array}$} & Senior management involvement \\
\hline & & & The cohesion of the team \\
\hline & & & Application of Kaizen technology \\
\hline \multirow[t]{3}{*}{3} & \multirow[t]{3}{*}{ The production triangle } & \multirow{3}{*}{$\begin{array}{l}\text { Implementation and application of tools and methods of lean } \\
\text { production in the production process of mechanical engineering, as } \\
\text { well as reducing losses in the form of the results of the } \\
\text { implementation of these methods }\end{array}$} & Application of $5 \mathrm{~S}$ system \\
\hline & & & Loss reduction \\
\hline & & & Application of pull system \\
\hline \multirow[t]{3}{*}{4} & \multirow[t]{3}{*}{ Resource triangle } & \multirow{3}{*}{$\begin{array}{l}\text { Work to improve the quality of products at all stages of the product } \\
\text { life cycle, as well as building mutually beneficial relationships with } \\
\text { suppliers. }\end{array}$} & Study of consumer needs \\
\hline & & & Improve product quality \\
\hline & & & Work with suppliers \\
\hline
\end{tabular}

The questionnaire was compiled, according to these indicators, and the answers to the questions were evaluated in points from 0 to 3 , where 0 -no indicator; 1 point-low level, no result; 2 points-average level, without continuous improvement of activities; 3 points-high level, continuous improvement of activities in this direction.

After, the results of the survey were transferred to "Table IV" and summarized.

TABLE IV. CALCULATION OF EVALUATION RESUlts

\begin{tabular}{|l|l|l|l|l|l|}
\hline № & \multicolumn{1}{|c|}{$\begin{array}{c}\text { Performance evaluation } \\
\text { The value of points after completing } \\
\text { the questionnaire }\end{array}$} & Amount \\
\hline 1 & Application of strategic management & 3 & 2 & 3 & 8 \\
\hline 2 & Lean manufacturing philosophy & 2 & 1 & 2 & 5 \\
\hline 3 & Availability of key performance indicators & 2 & 1 & 2 & 5 \\
\hline 4 & Senior management involvement & 3 & 3 & 3 & 9 \\
\hline 5 & The cohesion of the team & 3 & 3 & 3 & 9 \\
\hline 6 & Application of Kaizen technology & 3 & 2 & 3 & 8 \\
\hline 7 & Application of 5S system & 3 & 3 & 3 & 9 \\
\hline 8 & Loss reduction & 3 & 3 & 2 & 8 \\
\hline 9 & Application of pull system & 2 & 3 & 1 & 6 \\
\hline 10 & Study of consumer needs & 3 & 3 & 2 & 8 \\
\hline 11 & Improve product quality & 3 & 3 & 2 & 8 \\
\hline 12 & Work with suppliers & 3 & 2 & 2 & 7 \\
\hline
\end{tabular}


In the graphical representation, the lean wheel is shown in "Fig. 1".

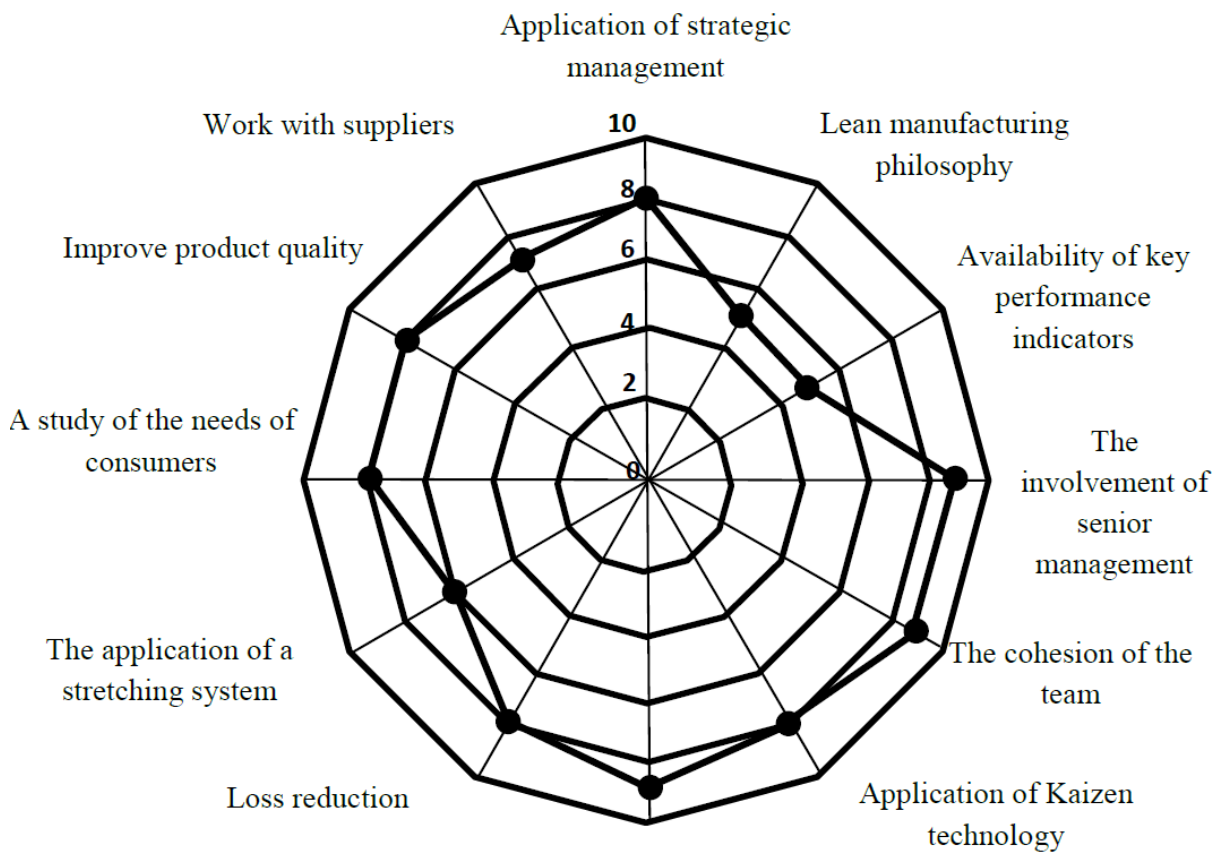

Application of 5S system

Fig. 1. Polygon (evaluation indicator) of lean manufacturing.

The polygon shows that it is necessary to increase the effectiveness of work on individual indicators. As a result of this analysis, it was revealed that the main problems that hinder the implementation of lean production are related to such indicators as key performance indicators, the application of lean production philosophy related to the strategic triangle, the use of the pull system, which refers to the production triangle.

As for compliance with the principles and methods of lean production, the following conclusion can be drawn: before the introduction of the concept of lean production, the company used these principles and methods either partially or not at all. However, the company plans to use: the method of rapid changeover SMED (flexibility, versatility of equipment); the principle of Kaizen (implementation of the system of promotion of innovative products); focus on the value of consumers (reducing delivery times, improving the level of service, response to claims, etc.).

As a solution to these problems, we can suggest the use of the principles of "Kaizen" and pulling production, as well as methods of TPM (universal care of equipment), "Just-intime" and methods to increase employee motivation.

In General, the company has achieved great results by implementing lean production tools, as the use of internal reserves of the company's development contributed to a significant improvement in operational indicators, such as the level of defects, inventory turnover, and production.

\section{CONCLUSION}

Summing up the results of the expert assessment in the form of a point-rating system and the construction of the lean production wheel of PJSC "ZAREM", we can note the main ways to solve the problems of implementing lean production at the enterprise:

- when implementing the implementation process, special departments should be created from qualified specialists for the development of the production system;

- implementation of lean production system should begin with the use of "5S" in a comprehensive manner;

- it is necessary to carry out a complete collection of data, allowing to analyze and conduct activities in all areas at the machine-building enterprise;

- develop a system of in-house staff training;

- the company should also develop an effective system of staff motivation, as well as material and moral incentives.

- it is necessary to consider the interests of the staff for a clear understanding of the philosophy of lean production and the identification of specific performance indicators to improve the quality of products in order to profit and improve the competitiveness of the enterprise. 
[14] I.A. Storozh. Algorithms of introduction of lean production (in the author's edition) [Electronic resource]. Access mode: http://www.riastk. ru/stq/adetail.php?ID=106223

[15] M.K. Ashinova, M.P. Khagurova and S.K. Chinazirova, "Lean production as a tool to improve the competitiveness of the enterprise", New technologies, 2018, Issue 2. Maykop: FGBOU IN "MGTU", 2018, Pp. 79-84.

\section{REFERENCES}

[1] O. Taiichi, "Toyota Production system. Moving Away from Mass Production". Moscow: Institute of integrated strategic studies, 2012, $208 \mathrm{p}$.

[2] S. Shingo, "The Study of the production system of Toyota from the point of view of the organization of production". Moscow: Institute of complex strategic studies, 2006, $312 \mathrm{p}$.

[3] S. Shingo, "Quick changeover: the Revolutionary technology to optimize production". Moscow: Alpina Business Books, 2006, 344 p.

[4] M. Imai, "Gemba Kaizen: the Way to reduce costs and improve quality". Moscow: Alpina Business Books, 2005, 346 p.

[5] G. Vumc, D. Jones and D. Rus, "The Machine that changed the world”. Moscow: Medley, 2007, 384 p.

[6] G. Vumc, J. Wumek and D. Jones, "Lean manufacturing: how to get rid of losses and achieve prosperity of your company", 7th ed. Moscow: Alpina Publisher, 2013, 472 p.

[7] M. Rother and J. Shook, "Learn to see business processes. The practice of mapping value stream". Moscow: Alpina Business Books, 2008, 144 p.

[8] H. Marchwinski and J. Shook, "Illustrated Glossary of lean manufacturing". Moscow: Alpina Business books: CBSD, business skills development Center, 2005, 123 p.

[9] T. Jackson, "Hoshin Kanri: how to make strategy work". Moscow: Institute of complex strategic studies, 2008, 248 p.

[10] J. Liker. "Tao Toyota: 14 principles of management of the leading company in the world", 5th ed. Moscow: Alpina Publishers, 2010. $402 \mathrm{p}$.

[11] J. Liker and D. Mayer, "Toyota Dao Practice: a guide to implementing Toyota management principles". Moscow: Alpina Business Books, 2008, 584 p.

[12] What do they read in production? Rating of books on the subject "production systems" // Business portal "Production Management" [Electronic resource]. Access mode: http://www.uppro.ru/library/production_management/systems//rejting-knig-ps.html

[13] Lean production [Electronic resource]. Access mode: http:// www.uppro.ru. 